\title{
Soil macrofauna as a bioindicator of soil quality in successional agroforestry systems
}

\author{
Macrofauna do solo como bioindicadora da qualidade do solo em sistemas agroflorestais \\ sucessionais
}

La macrofauna del suelo como bioindicador de la calidad del suelo en sistemas agroforestales sucessivos

Rafaela Martins da Silva

ORCID: https://orcid.org/0000-0002-7733-8208

Federal University of Viçosa, Brazil

E-mail: rfeng.florestal@gmail.com

Rakiely Martins da Silva

ORCID: https://orcid.org/0000-0001-6914-4721

North Fluminense State University, Brazil

E-mail: rakiely@hotmail.com.br

Sandra Santana de Lima

ORCID: https://orcid.org/0000-0003-3599-8344

Federal Rural University of Rio de Janeiro, Brazil

E-mail: sandra.biologa@hotmail.com

Jianne Rafaela Mazzini de Souza

ORCID: https://orcid.org/0000-0002-0803-4438

Federal University of Viçosa, Brazil

E-mail: jianne.rafaela@hotmail.com

Jheny Kesley Mazzini de Souza

ORCID: https://orcid.org/0000-0001-8188-4423

Federal University of São João Del Rei, Brazil

E-mail: Jheny.kesley@ hotmail.com

Gilberto Terra Ribeiro

ORCID: https://orcid.org/0000-0003-0882-8796 Sucupira Agroforests, Brazil

E-mail: gilbertoterra@gmail.com

Guilherme Montandon Chaer

ORCID: https://orcid.org/0000-0003-0734-2866

Brazilian Agricultural Research Corporation - Embrapa Agrobiology, Brazil

E-mail: guilherme.chaer@embrapa.br

\begin{abstract}
The objective of this study was to evaluate soil macrofauna as a bioindicator of soil quality in successional agroforestry systems and secondary forests. The study was conducted in the southern lower region of Bahia in Brazil, in two areas: a successional agroforestry system (AFS18) and native forest (NF). AFS18 consists of two species: mahogany (Khaya ivorensis and Khaya grandifoliola), açaí (Euterpe oleracea), cacao (Theobroma cacau) and banana (Musa spp.). Sampling was carried out in the dry (June) and rainy (October) seasons of 2019, and eight soil monoliths were collected in both areas. A total of 889 individuals from the soil macrofauna were sampled. The highest frequency (RF) of taxons occurred in NF in the rainy season, and the groups that stood out were: Oligochaeta with $42 \%$ FR in ASF18, Formicide with 33.9\% in NF and Isoptera with 58\% in AFS18. The macrofauna structure of the soil varied according to the time of collection. The density of macrofauna individuals differed between areas only in the dry season. The highest number of ind. $\mathrm{m}^{2}$ was observed in the area NF (378) when compared to ASF18 (196). TOC, $\mathrm{Mg}^{2+}, \mathrm{Al}^{3+}$ and CTC were related to AF on both occasions of collection and AFS18 in the rainy season, $\mathrm{K}^{+}, \mathrm{P}$ and $\mathrm{pH}$ were associated with AFS18 in the dry season. The diversity, equitability and richness of the soil macrofauna was greater in AF area. HFA18 in the rainy season was similar to NF, favoring colonization of the area by soil macrofauna organisms.
\end{abstract}

Keywords: Biodiversity; Soil fauna; Biological indicators; Soil recovery.

\section{Resumo}

O objetivo deste estudo foi avaliar a macrofauna do solo como um bioindicador da qualidade do solo em sistemas agroflorestais sucessionais e florestas secundárias. O estudo foi realizado na região do baixo sul da Bahia no Brasil, em duas áreas: um sistema agroflorestal sucessório (AFS18) e floresta nativa (NF). O AFS18 consiste em duas espécies: mogno (Khaya ivorensis e Khaya grandifoliola), açaí (Euterpe oleracea), cacau (Theobroma cacau) e banana 
(Musa spp.). A amostragem foi realizada nas estações seca (junho) e chuvosa (outubro) de 2019, e oito monólitos de solo foram coletados em ambas as áreas. Um total de 889 indivíduos da macrofauna do solo foram amostrados. A maior freqüência (RF) de táxons ocorreu na NF na estação chuvosa, e os grupos que se destacaram foram: Oligochaeta com 42\% RF na ASF18, Formicida com 33,9\% na NF e Isoptera com 58\% na AFS18. A estrutura macrofaunística do solo variou de acordo com o tempo de coleta. A densidade dos indivíduos da macrofauna diferiu entre as áreas somente na estação seca. O maior número de ind. $\mathrm{m}^{2}$ foi observado na área NF (378) quando comparado com a ASF18 (196). TOC, Mg2+, Al3+ e CTC foram relacionados com AF em ambas as ocasiões de coleta e AFS18 na estação chuvosa, $\mathrm{K}+, \mathrm{P}$ e pH foram associados com AFS18 na estação seca. A diversidade, equitabilidade e riqueza da macrofauna do solo foi maior na área AF. O HFA18 na estação chuvosa foi semelhante ao NF, favorecendo a colonização da área por organismos da macrofauna do solo.

Palavras-chave: Biodiversidade; Fauna do solo; Indicadores biológicos; Recuperação do solo.

\section{Resumen}

El objetivo de este estudio fue evaluar la macrofauna del suelo como bioindicador de la calidad del suelo en sistemas agroforestales sucesionales y bosques secundarios. El estudio se llevó a cabo en la región sur baja de Bahía en Brasil, en dos áreas: un sistema agroforestal sucesional (AFS18) y un bosque nativo (NF). El AFS18 está formado por dos especies: caoba (Khaya ivorensis y Khaya grandifoliola), açaí (Euterpe oleracea), cacao (Theobroma cacau) y plátano (Musa spp.). El muestreo se realizó en las estaciones seca (junio) y lluviosa (octubre) de 2019, y se recogieron ocho monolitos de suelo en ambas zonas. Se muestrearon un total de 889 individuos de la macrofauna del suelo. La mayor frecuencia (FR) de taxones se dio en NF en la época de lluvias, y los grupos que destacaron fueron: Oligochaeta con un $42 \%$ de FR en ASF18, Formicida con un 33,9\% en NF e Isoptera con un 58\% en AFS18. La estructura de la macrofauna del suelo varió en función de la época de recogida. La densidad de los individuos de la macrofauna difirió entre las zonas sólo en la estación seca. El mayor número de ind.m² se observó en la zona NF (378) en comparación con la zona ASF18 (196). El COT, el Mg2+, el Al3+ y el CTC se relacionaron con la AF en ambas ocasiones de recolección y con la AFS18 en la estación lluviosa, el K+, el P y el pH se asociaron con la AFS18 en la estación seca. La diversidad, equitatividad y riqueza de la macrofauna del suelo fue mayor en la zona de AF. El AFS18 en la estación lluviosa fue similar al NF, favoreciendo la colonización de la zona por los organismos de la macrofauna del suelo.

Palabras clave: Biodiversidade; Fauna del suelo; Indicadores biológicos; Recuperación del suelo.

\section{Intruduction}

Agroforestry systems (AFSs) are considered alternative production models, which have emerged as a sustainable alternative for agricultural production, a viable strategy for the recovery of degraded soils, assuming that the combination of tree species with agricultural crops and, or animals, can repair the chemical and physical attributes of degraded soils, as well as stimulate biological activity (Lu et al. 2015; Miccolis et al. 2016). The AFSs whose management advocates conducting local secondary succession are called "agroforestry succession systems" (Miccolis et al., 2016). These use biodiversity and the principles of ecological succession to produce food in a sustainable manner, favoring cycling and nutrient inputs to the soil (Alves et al., 2011).

Successional AFSs can perform these functions more efficiently, as they seek to mimic the structure, diversity and ecological interactions between species similar to natural forest ecosystems (Vieira et al., 2009). One of the benefits provided by AFSs is the increase in the production of "serrapilheira" (mulch) which, when deposited in the soil of agroforestry, increases the contribution of organic matter to the soil (Dantas et al., 2012; Silva et al., 2012).

Organic matter often added to the soil provides a nutrient-rich substrate for soil fauna (Lima et al. 2010; Martins et al. 2019) and soil microorganisms, increasing nutrient cycling and soil fertility levels (Cézar et al., 2015).

In this context, although the benefits of AFS are recognized, it is necessary to monitor these systems considering their composition, therefore the macrofauna soil assessment, together with the activity and abundance of soil communities can be used as indicators of soil quality and functioning (Correia, 2000; Melo et al., 2009). Most of the macrofauna organisms can be observed in the topsoil layer (0-10 cm depth), which is the layer most affected by management practices (Baretta et al., 2006). Macrofauna is composed of organisms with different functionality, which make them important components of some soil processes. The activities of some groups are differentiated, and consequently these groups Formicidae, Oligochaeta and 
Termitas are considered as soil engineers (Lavelle et al., 1997). The activities performed by soil invertebrates are considered as environmental services, therefore these organisms contribute to the sustainability and functioning of ecosystems (Lavelle et al., 2006; Brown et al., 2015)

Soil macroinvertebrates actively influence pedological processes through structural and mineralogical transformations (De Oliveira et al., 2014) and improvement of soil hydraulic properties, such as aeration and drainage (Leonard and Rajot, 2001). They act in the formation and stabilization of soil aggregates with implications in flood and erosion control (Brussaard et al., 2007), soil carbon storage and greenhouse gas emissions (Majeed et al., 2014). Furthermore, these organisms represent influencing agents under nutrient cycling processes (De Vries et al., 2013; Wagg et al., 2014). Therefore, they are able to indicate changes in physical-chemical characteristics (Velásquez et al., 2010) and structural characteristics of the environment in which they are found (Arias et al., 2015).

Successional agroforestry is still rare in Brazil, with small scale and empirical experiments. The projects of Fazenda Sucupira in the lower southern region of the state of Bahia, the Ribeira Valley in the state of São Paulo (Steenbock et al., 2013), the region of Paraty, southern coast of the state of Rio de Janeiro, as well as the farms of Ernst Götsch and Henrique Sousa, both in the state of Bahia (Peneireiro, 1999), and other Brazilian biomes (Miccolis et al., 2016), are noteworthy.

We assume that successional agroforestry favors the establishment of the community of soil macrofauna organisms, facilitating environmental recovery. Therefore, this study aimed to evaluate soil macrofauna as a bioindicator of soil quality in successional agroforestry systems and secondary forests in the southern lowlands of Bahia, Brazil.

\section{Methodology}

This study is an experimental research, whose data collected are quantitative in nature (Pereira et., 2018), collected on site (2.1 Description of study sites) and analyzed following the protocols described in the following sections.

\section{Description of study sites}

The study was conducted at Sucupira Farm, located in the municipality of Valença, southeastern Bahia State (Baixo Sul Bahia micro-region), Bahia State (UTM $0466283 \mathrm{~m} ; 8526145 \mathrm{~m}$, zone 24S). The relief of the region is wavy, with slopes higher than 10\%, characteristic of the morphoclimatic domain of the "Mares de Morros" (AB'SABER, 2000) present in the Brazilian coast. The average altitude is around $200 \mathrm{~m}$. In the farm predominate the Distrófico Yellow Argissolo (Santos et al., 2019). The area is under the dominion of the Atlantic Forest biome with predominant vegetation of Submontane Dense Ombrophylous Forest (IBGE, 2012). According to Köppen, the climate is of the humid tropical type (Af), with rainy winters and drier summers. The average annual temperature in Valença is $24.6{ }^{\circ} \mathrm{C}$ and average annual rainfall is $2109 \mathrm{~mm}$, ranging from $26.1{ }^{\circ} \mathrm{C}$ (January) to $22.6{ }^{\circ} \mathrm{C}$ (July). Two areas were selected for the study: Sucessional agroforestry system (SAF18) and native forest (NF). At Talhão 18 of Sucupira Farm, an area previously occupied by an abandoned pasture. In May 2018 the SAF18 was implemented, the area was opened for planting by means of mechanized rubbing followed by marking and opening of planting holes. Two African mahogany species (Khaya ivorensis and Khaya grandifoliola) were planted alternately in the same line with açaí (Euterpe oleracea). Between rows of mahogany and açaí rows alternated with banana (Musa spp.) were planted. Planting spacing was 6 by $6 \mathrm{~m}$, considering each species individually, or 3 by $3 \mathrm{~m}$, considering all species. In the planting, $200 \mathrm{~g}$ of limestone and $400 \mathrm{~g}$ of simple superphosphate were applied in the planting hole. A cover fertilization with formulated N-P-K 10:10:30 was applied at 6 months and 12 months after planting in the amount of $100 \mathrm{~g}$ per application per plant. Based on the classification proposed by Resolution CONAMA n 33 of 1994, the fragment of secondary forest (FN) located in the adjacencies of SAF18, was classified as forest in advanced stage of regeneration, presenting dominant arboreal physiognomy over the others, medium DAP above $14 \mathrm{~cm}$, average height above $12 \mathrm{~m}$, abundant burlap, great biological 
diversity, with herbaceous extract, shrubby, and an extract notably arboreal.

\section{Sampling and characterization of soil macrofauna}

Soil macrofauna sampling was carried out in two seasons, June and October 2019, using the UNESCO Tropical Soil Biology and Fertility (TSBF) programme (Anderson and Ingram, 1993) and according to Aquino (2001). In both areas, without the edges, eight soil monoliths were randomly collected with the aid of a $25 \mathrm{x} 25 \mathrm{~cm}$ to $10 \mathrm{~cm}$ depth template. The screening for macroinvertebrates removal from the soil (size $<2 \mathrm{~mm}$ ) was done manually with the help of tweezers and the collected organisms were preserved in $70 \%$ alcohol. Later, they were identified at order, class, or family level with the aid of a binocular magnifier.

\section{Soil Analysis of soil chemical}

In each monolith collected, a soil sample referring to a depth of 0-10 was taken for chemical characterization of the soil. Then, the following chemical analyses were prepared and submitted: $\mathrm{pH}$ in water, extractable phosphorus, exchangeable potassium and sodium, exchangeable calcium and magnesium, exchangeable aluminum and potential acidity, according to Donagema et al. (2010). The total organic carbon (TOC) content of the soil was determined by oxidation of organic matter according to Yeomans \& Bremner (1988).

\section{Statistical analysis}

The soil macrofauna density, obtained by calculating the number of individuals per $\mathrm{m} 2$ (ind. $\mathrm{m}^{2}{ }^{2}$ ) and its respective standard error, the total wealth index, and the average wealth, represented by the average number of groups present in each sample point per area, were also determined. In addition, the Shannon-Weaner ecological indexes were calculated using the formula $(\mathrm{H})=-\sum \mathrm{pi} * \log \mathrm{pi}$, where $\mathrm{pi}=\mathrm{ni} / \mathrm{N}$, where ni is the abundance of each group and $\mathrm{N}$ is the total abundance. Finally, the equitability index of Pielou was calculated using the formula (e) $=\mathrm{H} / \log \mathrm{S}$, where $\mathrm{H}$ corresponds to the Shannon-Weaner index and S corresponds to total wealth (Odum, 1988). The sampled organisms were grouped according to their functionality, as described by Brown et al. (2015).

The results of the soil chemical characterization, ind. $\mathrm{m}^{-2}$ and richness, were tested according to the ANOVA premises and the respective means were compared with the nonparametric Mann-Whitney test at 5\% significance, in the R software (R Development Core Team, 2019).

The abundance matrix of macrofauna taxon groups and soil chemical attributes obtained at each monitoring date was used to order the areas at each collection occasion (Rainy season and Dry season, respectively) by the nonmetric multidimensional scaling procedure (nMDS) (Kruskal and Wish, 1978). In addition, a hierarchical grouping analysis was performed in order to identify possible patterns of dissimilarity between the situations studied (areas, seasons). In this sense, the average abundance of all taxonomic groups was considered in order to obtain a dendrogram of dissimilarity developed by the Bray-Curtis distance, based on the paired groups method. Both multivariate analyses were performed using PC-ORD, Version 6 (MjM Software, Gleneden Bech, Oregon, U.S.A).

\section{Results}

The characterization of the soil macrofauna community is presented in Table 1. 
Table 1. Relative frequency and structural attributes of the edaphic macrofauna in successional groforestry system and secondary forest area in Valença-BA, 2019.

\begin{tabular}{|c|c|c|c|c|}
\hline \multirow[b]{2}{*}{ Groups } & \multicolumn{2}{|c|}{ Rainy season } & \multicolumn{2}{|c|}{ Dry season } \\
\hline & $\mathrm{NF}$ & AFS18 & $\mathrm{NF}$ & AFS 18 \\
\hline Oligochaeta & 25.4 & 42.0 & 24.9 & 14.1 \\
\hline Formicidae & 21.0 & 21.0 & 33.9 & 22.4 \\
\hline Isoptera & 21.0 & 29.5 & 13.2 & 58.0 \\
\hline Dermaptera & 3.0 & - & 5.3 & - \\
\hline Protura & 3.0 & - & 5.3 & - \\
\hline Coleoptera & 2.7 & - & 4.8 & - \\
\hline Coleoptera P. & 2.7 & - & - & - \\
\hline Isopoda & 2.4 & 5.7 & 2.1 & 3.9 \\
\hline Lepidoptera P. & 2.4 & - & - & - \\
\hline Blattodea & 2.1 & - & 3.2 & - \\
\hline Auchenorryncha & 1.8 & - & 3.2 & - \\
\hline Opilionida & 1.8 & - & - & - \\
\hline Chilopoda & 1.5 & 0.7 & - & 1.0 \\
\hline Formicidae 1. & 1.5 & - & - & - \\
\hline Symphyla & 1.2 & - & - & - \\
\hline Thisanura & 1.2 & - & - & 1.0 \\
\hline Others & 5.62 & 4.23 & 1.10 & 0.50 \\
\hline Total Abundance (Ind.m ${ }^{-2}$ ) & 670 & 584 & 378 & $196^{*}$ \\
\hline Shannon & 3.29 & 1.89 & 2.78 & 0.93 \\
\hline Total Richness & 23 & 13 & 16 & 9 \\
\hline Mean Richness & 6.88 & $3.33 *$ & 4.25 & $2.31 *$ \\
\hline Pielou & 0.73 & 0.63 & 0.75 & 0.57 \\
\hline
\end{tabular}

AFS18 - successional agroforestry system; NF - native forest; DS - dry season; RS - rainy season. * significant difference $(\mathrm{p}<0,05)$. Source: Authors.

In Table 1 it can be seen that the structure and composition of the macrofauna community was particular for each area sampled (NF and ASF18), presenting variations in diversity and frequency and activity (density of individuals). In the study areas (NF and ASF18) a total of 889 soil macrofauna individuals were sampled, representing 25 groups. In general, the taxons occurred more frequently (RF) in NF in the rainy season (Fig 1). Among the sampled groups, they stood out: Oligochaeta with 42\% FR in ASF18, Formicide with 33.9\% in NF and Isoptera with 58\% in ASF18, in seasons of distinct collections (Table 1).

The invertebrate macrofauna structure varied $(\mathrm{p}=0.0038)$ depending on the collection season (Rainy season and Dry season). The density (ind.m-2) of individuals differed $(\mathrm{p}=0.028)$ between areas only in the dry season (Table 1$)$. The largest number of ind. $\mathrm{m}^{2}$ observed in the area NF (378) when compared to ASF18 (196) (Table 1). While group richness (p=0.019), the Shannon diversity index in the NF area was 3.29 and 2.78, already in the ASF18 area: 1.89 and 0.93 (rainy and dry season) and the equitability of Pielou varied in the NF between 0.73 and 0.75 (rainy and dry season), while in the ASF18 area values were observed between 0.63 and 0.57 in rainy and dry season, they were higher in the NF area regardless of the time of collection (Table 1).

Figure 1a shows the graphical representation of the relationships between the structure of macrofauna and soil chemical attributes, ordered according to the areas studied (NF and AFS18) and the respective collection season (rainy and dry). Figure $1 \mathrm{~b}$ shows the grouping of the macrofauna community according to its similarity in relation to the composition 
observed in each area (NF and AFS18) at the time of collection (rainy and dry).

Figure 1. (a) Non-metric multidimensional scaling (NMDS) of macrofauna taxonomic groups and soil chemical attributes; (b) Dissimilarity dendrogram according to the average abundance of the groups taxonomic characteristics of soil macrofauna in successional agroforestry and secondary forest, Valença-BA, 2019. AFS18 - successional agroforestry system; NF - native forest. Auch: Auchenorryncha; Blatt: Blattodea; Coleo: Coleoptera; Chilo: Chilopoda; Derm: Dermaptera; Isop: Isopoda; Isop: Isoptera; Formi: Formicidae Oligo: Olgichaeta; Opil: Opilionoda; Prot: Protura; Symp: Symphyla. Others: taxonomic groups with lower relative participation at $5 \%$.

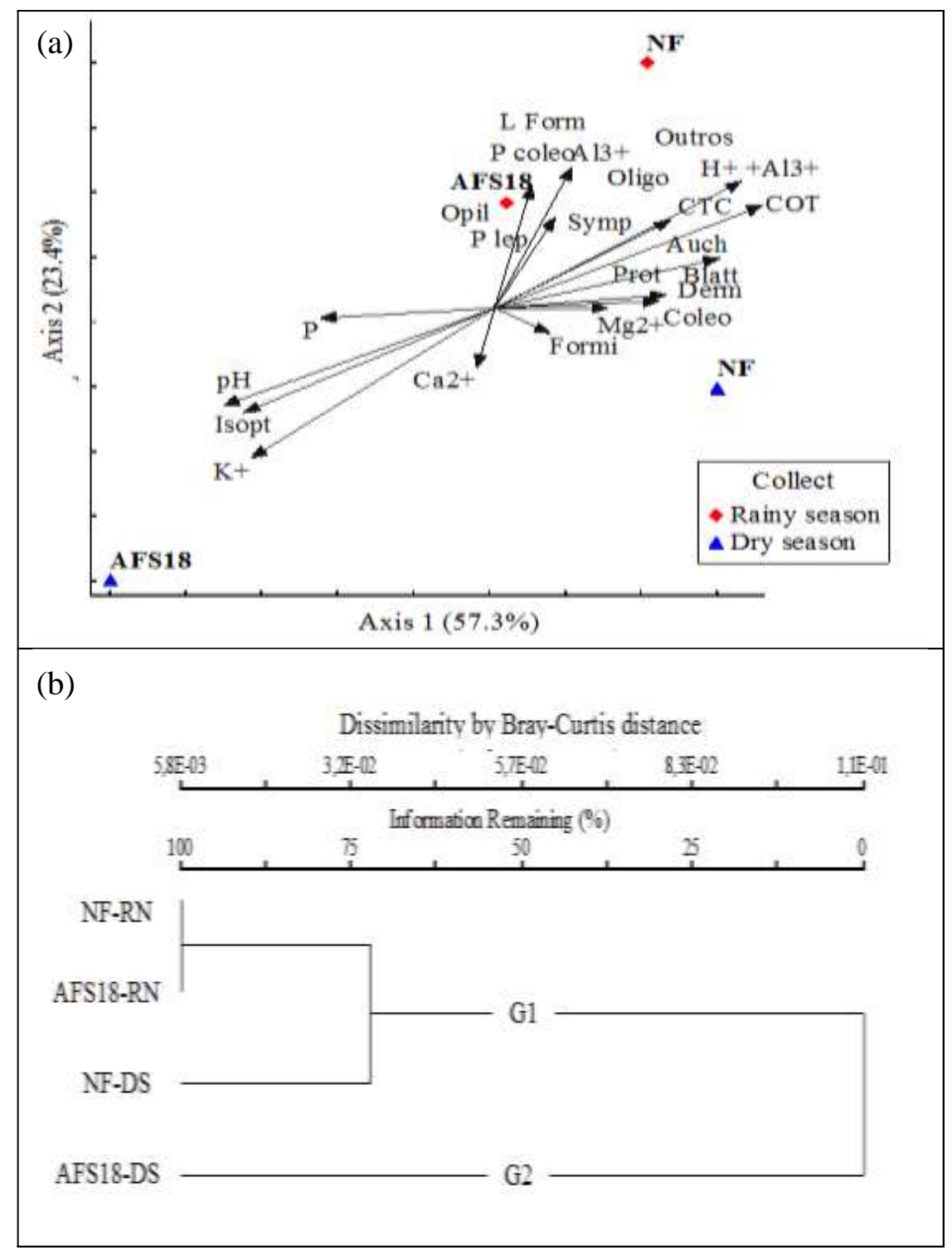

Source: Authors.

Figure 1a shows the graphical representation of the relationships between the structure of macrofauna and soil chemical attributes, ordered according to the areas studied (NF and AFS18) and the respective collection season (rainy and dry). Figure $1 \mathrm{~b}$ shows the grouping of the macrofauna community according to its similarity in relation to the composition observed in each area (NF and AFS18) at the time of collection (rainy and dry).

The nonmetric multidimensional scaling (nMDS) relating the composition of the invertebrate macrofauna and the soil 
chemical attributes in the FN and AFS18 areas as a function of the collection explained $80.7 \%$ of the variance between the areas, the axis 1 contributed $57.3 \%$ while the axis $2,23.4 \%$ of the data variability was explained (Figure 1a).

The ordering of the areas indicates proximity between NF and AFS18 areas in the rainy season (Fig 1a). TOC, Mg2+, $\mathrm{Al} 3+, \mathrm{CTC}$ and potential acidity were related to AFS18 in both rainy and dry season and AFS18 only in the rainy season, already in the dry season, $\mathrm{K}+\mathrm{P}$ and $\mathrm{pH}$ were associated with AFS18 in the dry season. It is also observed that in general the higher abundance of macrofauna groups is positively related to the rainy season and AFS18 area in this occasion and to FN independent of the harvest season.

According to the hierarchical grouping diagram (Fig 1b), we observed the formation of two distinct groups (G1 and G2). G2 was formed only by AFS18 area in the dry season, while G1 was composed of two grouping levels, FN and AFS in the rainy season (level 1), and separating FN in the dry season (level 2). Level 2 showed 74\% dissimilarity of level 1, formed by grouping FN and AFS areas in the rainy season, where no dissimilarity was detected between the areas.

\section{Discussion}

The diversity, equitability and average richness and density (in the dry season) of soil macrofauna were favored with higher values observed in the area of native flora (NF) when compared to the studied agroforestry system (AFS18) (Table 1). The AF area is in a more advanced stage of regeneration, reflected in greater floristic diversity, contribution of soil organic matter and therefore with more food availability to soil organisms, which results in increased diversity and abundance of soil fauna in this ecosystem (Camara et al., 2018a; Martins et al., 2019). While the SAF18 is a recent establishment area (2018), and is in the process of recovery, migrating from abandoned pasture to a structure of high diversity and with the arboreal and shrub component predominating in relation to the old herbaceous component, with the positive effects of the new form of land use little pronounced. Plant cover and different cropping systems are directly related to the soil invertebrate fauna population, reducing the density and diversity of communities in relation to a forest area (Coyle. et al., 2015).

The greater heterogeneity provided by a balanced environment, as is the case of the area of native forest (FN) leads to less variation in temperature, greater availability of food for the organisms due to greater input of organic material and, consequently, better soil conditions and greater supply of microhabitats, determinants for the development of individuals (Silva et al., 2012; Franco et al., 2016).

The groups Oligochaeta, Isoptera, Formicidae and Coleoptera were highlighted due to their greater abundance in both areas (Table 1), are very important components of soil biota, acting as ecosystem engineers (Oligochaeta, Isoptera and Formicidae) burlap shredders, burlap transformers or predators (Lima et al., 2013). These organisms are capable of modifying pedoenvironmental characteristics, through activities and displacements, producing biopores and aggregates that affect the soil physical properties, such as water infiltration rate mutual influence between organic matter decomposition processes, nutrient cycling and bioturbation are responsible for the balance between the carbon stock in the soil and the emission of greenhouse gases (lavelle et al., 1997; Velásquez et al., 2012; Ferreira et al., 2020).

The ordering of the areas under study (Fig 1a) discriminates a positive relationship between the abundance of groups and the rainy season, as observed in this study, the pattern of influence of seasonality on the structure of the soil community, as well as on the increase of populations, has been verified by several studies (Lima et al., 2010; Cunha-Neto et al., 2012; Coyle et al., 2017; Pereira et al., 2020), which explain that the differences observed between the months, seasons or periods analyzed are mainly associated with precipitation.

The proximity between NF and AFS18 areas in the rainy season highlighted by nMDS (Fig 1a) indicates that in favorable conditions (without hydric stress, for example), AFS18 area also promotes the colonization of macrofauna, corroborated by the similarity between the density of individuals in the areas compared in the rainy season (Table 1), other 
studies also show the efficiency of agroforestry systems in restoring soil quality and increasing macrofauna diversity and abundance in degraded soils (Lima et al, 2010; Franco et al., 2016; Martins et al., 2019). The reduction of different guilds in the dry season, as observed in this study indicates that the soil environment at that time was less stable (Ferreira et al., 2017), and this condition, unfavorable to the dynamics of decomposition of the burlap and consequently, of nutrient cycling (Frasson et al., 2016).

Studies have suggested that soil chemical properties impact soil invertebrate communities (Birkhofer et al., 2012) and that fauna, especially soil engineers, can affect chemical properties (Lavelle et al., 1997; Franco et al., 2016). Oligochaetas associate positively with TOC, CTC and potential acidity in the ASF18 area (Fig 1a). In sustainable agrosystems, these organisms benefit plant metabolism and agricultural production, promote greater nitrogen fixation activity, greater quantities of available macro and micronutrients and polysaccharides, and greater biosynthesis of plant growth regulators (Negassa and Sileshi, 2018). In addition, they are sensitive to nutritional status and MOS levels and are abundant under sustainable systems where sufficient organic material is generally available (Li et al., 2017). Possibly, $\mathrm{K}+$ and P were related to ASF18 due to the fertilizations made for the maintenance of the crops conducted there.

The dissimilarity between the areas at different times (rainy and dry, respectively) (Fig 1b), corroborates the ordering of the areas based on the abundance of soil groups and chemical attributes (Fig 1a). Although the greatest diversity and richness of individuals were pronounced in NF, the dissimilarity diagram indicates that the ability of the environment to regain equilibrium after suffering environmental disturbances conditioned the distinction of groups, since only in the dry season, where water availability was a limiting factor for AFS18 that distanced itself from the NF area. Additionally, it is important to note that the AFS18 area was established under degraded area, so the system is still developing in the sense of environmental balance, different from the studied native forest (NF) where the regeneration stage is advanced.

The influence that soil organisms can exert on other soil attributes, observed in this study, as well as the role of the Oligochaeta group in Pedogenetic processes bring important contributions to the understanding of the recovery process in degraded areas based on the implementation of agroforestry systems, so that they are recovered and become productive. In addition, the diversity and abundance of invertebrate macrofauna organisms indicates that management is contributing to the promotion of important environmental services, to which organisms make an important contribution.

\section{Conclusion}

The higher diversity, equitability and richness of the macrofauna in the native forest area were favored by both the structure of the area and the collection period.

The abundance of important groups of macrofauna, such as soil engineers, in both collection periods indicates the benefits of agroforestry management.

The positive association of Oligochaetes and soil attributes with organic matter are strong indications of the efficiency of agroforestry management on soil quality.

The similarity of the successional agroforestry system in the rainy season with the native forest, regarding the community of macrofauna invertebrates, can be considered a positive factor, indicating sustainable conditions of the system. The relationships between the management of the agro-ecosystem and the dynamics of soil biota still lacks further explanations, being of utmost importance the establishment of studies, such as the use of agroforestry systems as an alternative for the recovery of degraded areas, it is important to monitor and understand how these production systems influence the biological processes and their contributors, in order to validate with greater robustness the eligibility of these systems for functional restoration of degraded ecosystems. 


\section{References}

Ab'Saber, N. A. (2000). Fundamentos da geomorfologia costeira do Brasil atlântico iter e subtropical. Revista Brasileira de Geomorfologia, 1:27-43. UGB/UFU Uberlândia.

Anderson, J. M., Ingram, J. S. I. (1993). Tropical soil biological and fertility: A Handbook of methods. 2. ed. Wallingford: C.A.B. International.

Alves, T. S., Campos, L. L., Neto, N. E., Matsuoka, M., Loureiro, M. F. (2011). Biomassa e atividade microbiana de solo sob vegetação nativa e diferentes sistemas de manejos. Acta Scientiarum. Agronomy Maringá, 33(2): 341-347.

Aquino, A. M. (2001). Manual para macrofauna do solo. Seropédica: Embrapa Agrobiologia, 21p. (Embrapa-CNPAB. Documentos, 130).

Arias, A. R. L. et al. (2015). Utilização de bioindicadores na avaliação de impacto e no monitoramento da contaminação de rios e córregos por agrotóxicos. Enciclopédia Biosfera, 11(22): 61-72.

Baretta, D., Mafra, A. L., Santos, J. P. C., Amarante, C. V. T., Bertol, I. (2006). Análise multivariada da fauna edáfica em diferentes sistemas de preparo e cultivo do solo. Pesquisa Agropecuária Brasileira, 41(11): 1675-1679.

Baretta, D., Santos, J. P. C., Segat, J. C., Geremia, E. V., Oliveira, F. L. C. L., Alves, M. V. (2011). Tópicos em Ciências do solo: Fauna edáfica e qualidade do solo. Sociedade Brasileira de Ciência do Solo, 7: 141-192.

Birkhofer, K. et al. (2012). General relationships between abiotic soil properties and soil biota across spatial scales and different land-use types. PLoS ONE 7:e43292.

Brown, G. G., Maschio, W., Froufe, L. C. M. (2009). Macrofauna do solo em sistemas agroflorestais e Mata Atlântica em regeneração nos municípios de Barra do Turvo, SP, e Adrianópolis, PR. Documentos, 184. Embrapa Florestas.

Brussaard, L., De Ruiter, P. C, Brown, G. G. (2007). Soil biodiversity for agricultural sustainability. Agric. Ecosyst. Environ. 121: $233-244$.

Camara, R. et al. (2018a). Effects of natural Atlantic Forest regeneration on soil fauna, Brazil. Floresta e Ambiente, Seropédica, $25(1)$ : e20160017.

Cézar, R. M. et al. (2015). Soil biological properties in multiestrata successional agroforestry systems and in natural regeneration. Agroforestry Systems, 89(6): 1035-1047.

Coyle, D. R. et al. (2017). Soil fauna responses to natural disturbances, invasive species, and global climate change: Current state of the science and a call to action. Soil Biology and Biochemistry, Oxford, 110: 116-133.

Correia, M. E. F., Oliveira, L. C. M. (2000). Fauna do solo: aspectos gerais e metodológicos. Documentos, 112. Embrapa Agrobiologia.

Cunha, F. V. et al. (2012). Soil fauna as an indicator of soil quality in forest stands, pasture and secondary forest. Rev. Bras. Ciênc. Solo, 36(5): 1407-1417, Nov. <http://www.scielo.br/scielo.php?script=sci_arttext\&pid=S0100-06832012000500004\&lng=en\&nrm=iso>.http://dx.doi.org/10.1590/S010006832012000500004 .

Oliveira, F. S., Varajao, A.F. D. C., Varajao, C. A. C., Schaefer, C. E. G. R., Boulange, B. (2014). The role of biological agents in the microstructural and mineralogical transformations in aluminium lateritic deposit in Central Brazil. Geoderma 226: 250-259.

Vries, F. T., Thebault, E., Liiri, M., Birkhofer, K., Tsiafouli, M. A., Bjornlund, L, et al. (2013). Soil food web properties explain ecosystem services across European land use systems. Proc. Natl. Acad. Sci. U. S. A. 110: 14296-14301.

Donagemma, G. K. et al. (2011). Manual de métodos de análises de solos. 2. ed. Rio de Janeiro, RJ: Embrapa Solos. 230 p. (Documentos/Embrapa Solos, 132).

Franco, A. L. C. et al. (2016). Loss of soil (macro)fauna due to the expansion of Brazilian sugarcane acreage. Science of the Total Environment, 563(564): $160-168$.

Ferreira, C. R. et al. (2020). Dynamics of soil aggregation and organic carbon fractions over 23 years of no-till management. Soil \& Tillage Research, Amsterdam, 198(1): 1-9.

Ferreira, C. R. et al. (2017). Edaphic arthropods in different successional stages of Atlantic forest and abandoned pasture areas. Comunicata Scientiae, Bom Jesus, 8(2): 296-306.

Frasson, J. M. F. et al. (2016). Litter decomposition of two pioneer tree species and associated soil fauna in areas reclaimed after surface coal mining in Southern Brazil. Revista Brasileira de Ciência do Solo, Viçosa, MG, 40: e0150444.

Instituto Brasileiro De Geografia e Estatística - IBGE. (2012). Manual técnico da vegetação brasileira, 2 Ed., Rio de Janeiro: Fundação Instituto Brasileiro de Geografia e Estatística. 271 p.

Heisler, C., Kaiser, E. A. (1995). Influence of agricultural traffic and crop management on Collembola andmicrobial biomass in arable soil. Biology and Fertility of Soils, 19(2/3)159-165.

Kruskal, J. B. \& M. Wish. (1978). Multidimensinal Scaling.Sage Publicstions, Bevery Hills, California.93p.

Lavelle, P., Bignell, D. E., Lepage, M., Volters, V., Roger, P., Ineson, P., Heal, W., Dillion, S. (1997). Soil function in a changing world: the role of invertebrate ecosystem engineers. European Journal of Soil Biology, 33(4): 159-193.

Leonard, J., Rajot, J. L. (2001). Influence of termites on runoff and infiltration: quantification and analysis. Geoderma 104: 17-40. 
Li, Y., Dong, Z. Y., Pan, D. Z., Pan, C. H., Chen, L. H. (2017). E ect of termite on soil pH and its application for termite control in Zhejiang province, China. Sociobiology, 64: 317-326.

Lima, S. S., Aquino, A. M., Leite, L. F. C., Velasquez, E., Lavelle, P. (2010). Relação entre macrofauna edáfica e atributos químicos do solo, em diferentes agroecossistemas. Pesquisa Agropecuária Brasileira, 45: 322 - 331.

Lima, A. C. R. et al. (2013). A functional evaluation of three indicator sets for assessing soil quality. Applied Soil Ecology, Amsterdam, 64: 194-200.

Lu, S., Wang, F., Meng, P., Zhang, J. (2015). Simultaneously protecting the environment and its residents: The need to incorporate agroforestry principles into the ecological projects of China. Ecological Indicators, 57: 61-63.

Majeed, M. Z., Miambi, E., Barois, I., Randriamanantsoa, R., Blanchart, E., Brauman, A. (2014). Contribution of white grubs (Scarabaeidae: Coleoptera) to N2O emissions from tropical soils. Soil Biol. Biochem. 75: 37-44.

Martins, E. M., Silva, E. R., Campello, E. F. C., Lima, S. S., Nobre, C. P., Correia, M. E. F., Resende, A. S. (2019). O uso de sistemas agroflorestais diversificados na restauração florestal na Mata Atlântica. Ciência Florestal, 29(2): 632-648.

Melo, F. V., Brown, G. G., Constantino, R., Louzada, J. N. C., Luizão, F. J., Mortis, J. W., Zanetti, R. (2009). A importância da meso e macrofauna do solo na fertilidade e como bioindicadores. Boletim informativo do SBCS. Janeiro-Abril.

Miccolis, A. et al (2016). Restauração ecológica com sistemas agroflorestais: como conciliar conservação com produção: opções para Cerrado e Caatinga. Brasília: Centro Internacional de Pesquisa Agroflorestal, p.266.

Negassa, W., Sileshi, G. W. (2018). Integrated soil fertility management reduces termite damage to crops on degraded soils in western Ethiopia. Agric. Ecosyst. Environ, 251: 124-131.

Peneireiro, F. M. (1999). Sistemas agroflorestais dirigidos pela sucessão natural: um estudo de caso. Dissertação de mestrado. Piracicaba/USP/ESALQ.

Pereira, J. M.et al (2020). Fauna edáfica e suas relações com atributos químicos, físicos e microbiológicos em Floresta de Araucária. Ciência Florestal, 30: (1): $242-257$

Odum, E. P. (1988). Ecologia. Rio de Janeiro: Guanabara, 434p.

R Development Core Team (2019). R: A Language and Environment for Statistical Computing. Vienna, Austria: R Foundation for Statistical Computing.

Santos, P. Z. F., Crouzeilles, R., Sansevero, J. B. B. (2019). Can agroforestry systems enhance biodiversity and ecosystem service provision in agricultural landscapes? A metaanalysis for the Brazilian Atlantic Forest. Forest Ecology and Management, 433: 140- 145.

Silva, E. A. S., Silva, C. A., Silva, I. R., Marques, J. J. G. S. M., Araujo, E. F., Carvalho, A. S., Silva, S. H. G., Curi, N. (2012). Frações de C em topossequencia de solos sob eucalipto com diferentes históricos de uso. Rev Bras Cienc Solo, 36:1167-78.

Souza, M. H., Vieira, B. C. R., Oliveira, A. P. G., Amaral, A. A. (2015). Macrofauna do Solo. Enciclopédia Biosfera, Centro Científico Conhecer - Goiânia, 11 (22).

Steenbock, W. et.al. (2013). Avaliação da dinâmica do carbono em agroflorestas desenvolvidas por agricultores associados à Coopera floresta. In: Agrofloresta, ecologia e sociedade, p 345-362. Curitiba: Kairós.

Velásquez, J., Tejera, R., Hernando, A., Núñes, M. V. (2010). Environmental diagnosis: integrating biodiversity conservation in management of Natura forest spaces. Journal for Nature Conservation, 18(4): 309-317.

Velásquez, E. et al. (2012). Soil macrofauna-mediated impacts of plant species composition on soil functioning in Amazonian pastures. Applied Soil Ecology, 56(1):43-50.

Vieira, D. L. M., Holl, K. D., Peneireiro, F. M. (2009). Agro-sucessional restoration as a strategy to facilitate tropical forest recovery. Restoration Ecology. 17(4): 451-459.

Wagg, C., Bender, S. F., Widmer, F., Van, Der. Heijden, M. G. A. (2014). Soil biodiversity and soil community composition determine ecosystem multifunctionality. Proc. Natl. Acad. Sci. U. S. A, 111: 5266-5270.

Yeomans, J. C., Bremner, J. M. A. (1988). Rapid and precise method for routine determination of organic carbon in soil. Communications in Soil Science and Plant Analysis, 19(13): 1467-1476. DOI: 10.1080/00103628809368027 